\title{
ANALISIS INTERAKSI EDUKATIF ANTARA GURU DAN PESERTA DIDIK KELAS XII SMAN 1 JAWAI
}

\author{
Reza Rismunandar, Aminuyati, Okianna \\ Program Studi Pendidikan EkonomiFKIP Untan Pontianak \\ Email: rezarismunandarsambas@gmail.com
}

\begin{abstract}
This study aims to determine the interaction between teachers and students in economic learning. The method in this research uses descriptive qualitative method with the form of research, namely case study research. The subjects of this study were 30 teachers of class XII SMA Negeri 1 Jawai. The data collection techniques used in this research are direct observation techniques with data collection tools in the form of observation sheets of student learning activities, interviews, and documentation. The indicators seen from economic learning activities (1) attract students' attention (2) motivate students (3) structure of the lesson (4) remind the topics that are mastered with new topics (5) respond to situations (6) convey information (7) explain giving motivation (8) Express personal opinion (9) Focus attention (10) Summarize the main points of the lesson (11) Provide psychological encouragement to students (12) Provide instructions for subsequent lessons (13) Conduct evaluation. Based on the data, the results can be obtained and it can be concluded that the educational interaction between teachers and students is quite good.
\end{abstract}

\section{Keywords: Economic, Educational Interactionslphabetic, Learning}

\section{PENDAHULUAN}

Interaksi edukatif menjadi bagian yang erat dalam kehidupan manusia. Sebagian besar kehidupan manusia diisi dengan komunikasi, baik dengan anggota keluarga, teman, tetangga, sejawat, maupun dengan diri sendiri. Lewat komunikasi, manusia bisa saling tukar informasi, berbagi, mengembangkan diri, dan berbagai manfaat lainnya. Pendidikan adalah proses komunikasi yang bertujuan dalam menciptakan manusia yang berfikir kreatif, mandiri serta dapat membangun diri dan masyarakat. Pendidikan ibarat uang logam, selalu memiliki dua sisi. Yakni, satu pihak yang bertugas mengajar, sedangkan di pihak lainnya tugasnya belajar. Satu sisi memberi dan sisi lainnya menerima. Pendidikan adalah salah satu kebutuhan dan kewajiban bagi umat manusia dalam kehidupannya.
Pendidikan berfungsi untuk meningkatkan mutu kehidupan manusia, baik sebagai individu maupun sebagai kelompok dalam kehidupan bermasyarakat. Pendidikan merupakan usaha sadar untuk menumbuh kembangkan potensi sumber daya manusia melalui kegiatan belajar. Dalam proses pembelajaran mengacu pada aktivitas guru dan aktivitas siswa saat pelaksanaan proses pengajaran di dalam kelas. Kesusksesan dalam belajar-mengajar dapat dilihat dari hasil, tetapi harustetap diperhatikan prosesnya. Pada proses inilah sisiwa akan melakukan kegiatan belajar-mengajar. Proses yang baik dan benar kemungkinan besar akan memberikan hasil yang baik pula" (Sardiman, 2007:1). Hasil belajar akan menjadi optimal jika ada interaksi edukatif yang baik dikelas. Interaksi edukatif harus menggambarkan hubungan akif dua arah dengan pengetahuan sebagai mediumnya, sehingga interaksi ini 
merupakan hubungan yang bemakna dan kreatif. Dengan demikian siswa diharapkan lebih aktif dalalm kegiatan belajar- mengajar dan juga membuat hasil belajar siswa menjadi lebih baik. Interaksi edukatif adalah interaksi yang berlangsung dalam suatu ikatan untuk melaksankan tujuan pendidikan dan pengajaran atau lebih dikenal dengan istilah interaksi belajar-mengajar" (Sardiman, 2007:1). Interaksi edukati unsur guru dan anak didik harus aktif, tidak mungkin terjadi interaksi edukatif bila hanya ada satu unsur yang aktif. Aktif dalam arti sikap, mental, dan perbuatan. Dalam proses pembelajaran dikelas, terkadang guru (komunikator) tidak dapat menyampaikan pesannya dengan baik karena murid (komunikan) sulit dalam memahami pesan apa yang disampaikan oleh guru. Sulitnya murid dalam memahami pesan yang disampaikan guru disebabkan oleh beberapa hal yang terjadi dalam komunikasinya. Tidak hanya guru terkadang siswa lebih sering tidak mendengarkan dan mengemukakan pendapat terhadap materi yang telah disampaikan. Banyak orang berpendapat bahwa orang yang mempunyai keberhasilan belajar yang maksimal, karena adanya pola komunikasi yang baik antara guru dan siswa. Dalam pembelajaran akan selalu dibarengi dengan proses interaksi dan komunikasi. Pola komunikasi yang tidak sesuai akan membawa akibat terhadap pesan yang disampaikan oleh guru. Sardiman (2012:2) menyatakan bahwa interaksi belajar mengajar mengandung arti "Adanya kegiatan interaksi dari tenaga pengajar yangmelaksanakan tugas pengajar di satu pihak, dengan warga belajar (siswa, anak didik/subjek belajar) yang sedang melaksanakan kegiatan belajar dipihak lain". Dalam proses belajar mengajar, siswa menduduki peran yang sangat penting, karena siswa yang menjadi tolak ukur berhasil tidaknya proses belajar mengajar oleh karena itu keberadaan dan peran aktif siswa mutlak diperlukan dalam proses belajar mengajar. Siswa dituntut untuk selalu aktif memproses dan mengolah hasil pembelajarannya. Untuk dapat memproses dan mengolah hasil belajarnya secara efektif siswa dituntut untuk aktif secara fisik, intelektual dan emosional. Impikasi prinsip keaktifan bagi siswa berwujud perilaku seperti mencari sumber informasi, menganalisis hasil percobaan dan lain sebagainya. Berdasarkan hasil observasi pada tanggal 20 januari di SMAN 1 Jawai pada kelas X II IPS 1 bisa dilihat peserta didik kurang aktif dalam mengikuti pelajaran. Pada saat guru menjelaskan masih banyak siswa yang berbicara dengan teman sebangkunya, memainkan handphone, tidak bergairah menerima materi, ijin keluar kelas, bahkan hanya berdiam diri dan mendengarkan tanpa memberikan timbal balik terhadap guru. Sehingga guru berinteraksi dengan sebagian kecil siswa dikelas. Hal ini menyebabkan guru lebih aktif dan dominan pada saat dikelas sehingga interaksi antara guru dan siswa yang terjadi kurang maksimal dan membuat siswa menjadi pasif dan kurang kreatif. Guru yang lebihaktif dan dominan didalam kelas membuat siswa hanya mendengarkan tanpa hasrat ingin bertanya atau menjawab serta memberikan ideide atau pendapat tentang materi yang sedang dijelaskan. Dalam observasi yang dilakukan peneliti juga menemukan bahwa minat belajar siswa yang sangat kurang karena interaksi yang diangun oleh guru kurang menarik sehingga minat untuk belajar menjadi berkurang. Ketika guru menjelaskan didepan dan dihadapkan pertanyaan kepada siswa, hanya ada beberapa yang berkeinginan untuk menjawab lalu sebagian besar hanya terdiam, ada yang malah tertidur, Padahal guru adalah salah satu pemberi informasi yang sangat penting. Interaksi yang baik antara guru dan siswa, interaksi ini memegang peranan yang sangat penting dalam meningkatkan hasil belajar siswa, sebab bagaimanapun baiknya materi yang disampaikan, bagaimanapun sempurnanya metode yang digunakan, jika tidak terjalin hubungan yang harmonis antara guru dengan siswa, maka pada akhirnya menghasilkan hasil belajar yang kurang memuaskan. Untuk mencapai interaksi belajar mengajar dan mebangun minat siswa dalam belajar perlu adanya pola komunikasi yang tepat antara guru dengan siswa, sehingga terpadu dua kegiatan yang berdaya guna dalam mencapai tujuan pengajaran dan pendidikan dimana siswa dapat sukses dalam tugas belajarnya begitu pula guru dapat berhasil mengajar dan mendidik sesuai dengan tujuan yang hendak dicapai. Oleh karena iu peneliti tertarik melakukan penelitian berjudul "Analisis Interaksi Edukatif Guru dan Peserta Didik Dalam Pembelajaran Ekonomi Di Kelas XII IPS 1 SMAN 1 Jawai” 


\section{METODE PENELITIAN}

Metode penelitian menjelaskan tahapan penelitian atau pengembangan yang dilakukan untuk mencapai tujuan/sasaran penelitian. Tiap tahap dijelaskan secara ringkas, misalnya tiap tahap dalam satu paragraf.

Metode penelitian yang digunakan harus sesuai dengan masalah yang diteliti. Berdasarkan masalah yang dirumuskan dalam penelitian ini, maka metode yang digunakan adalah metode deskriptif. Untuk melihat interaksi edukatif antara guru peserta didik dalam pembelajaran ekonomi diSMAN 1 Jawai sesuai dengan butir-butir masalah dan indikator, tujuan dan manfaat penelitian, maka dalam penelitian ini peneliti akan menggunakan pendekatan penelitian kualitatif.

Bentuk penelitian yang digunakan dalam penelitian ini adalah studi kasus. Menurut Emzir (2014:20) "Penelitian studi kasus adalah suatu penelitian kualitatif yang berusaha menemukan makna, menyelidiki proses dan memperoleh pengertian dan pemahaman yang mendalam dari individu, kelompok, atau situasi"

Lokasi penelitian ditentukan sesuai dengan masalah dan subjek yang akan di teliti, maka lokasi untuk penelitian ini yaitu di SMAN 1 Jawai. Peneliti memilih lokasi penelitian ini dikarenakan untuk mengetahui interkasi eduktif dalam pembelajaran ekonomi di SMAN 1 Jawai.

Teknik pengumpulan data adalah langkahlangkah yang diperoleh oleh peneliti untuk memperoleh data dalam usaha pemecahan masalah yang diambil.

Menurut Sugiyono (2019:308) “Teknik pengumpulan data merupakan langkah yang paling utama dalam penelitian, karen tujuan utama dari penelitian ini adalah mendapatkan data. Tanpa mengetahui teknik pengumpulan data, maka peneliti tidak akan mendapatkan data yang memenuhi standar yang ditetapkan".

Menurut Sugiono (2019:309) ada 3 macam teknik pengumpula data, sebagai berikut; Observasi, Wawancara / Interview, Dokumentasi, Triangulasi / Gabungan. Berdasarkan teknik pengumpulan data yang digunakan maka alat yang digunakan didalam penelitian ini adalah pedoman wawancara dan lembar observasi.

Menurut Emzir (2014:85) "Analisis data kualitatif merupakan proses sistematis pencarian dan pengaturan transkripsi wawancara, catatan lapangan, dan materi-materi lain yang telah dikumpulkan dan disajikan apa yang sudah ditemukan kepada orang lain". Analisis data dalam penelitian ini adalah reduksi data, data display, verification.

Sugiyono (2019:363) menyatakan "Uji keabsahan data dalam penelitian, sering hanya ditekankan pada uji validitas dan realibilitas". Menurut Sugiyono (2019:366), mengatakan bahwa "uji keabsahan data dalam penelitian kualitatif meliputi uji, credibility (validitas internal), transferablitiy (validitas eksternal), dependablity (reliabilitas), dan comfirmability (obyektivitas)"

\section{HASIL PENELITIAN DAN PEMBAHASAN Hasil Penelitian}

Bentuk interaksi edukatif antaraguru dan peserta didik pada saat membuka proses pembelajaran ekonomi yang berlangsung dikelas XII IPS 1 SMAN 1 Jawai antara lain :

Menarik perhatian peserta didik, secara lisan guru mengucapkan salam pada saat masuk ke kelas, peserta didik dengan serempak menjawa salam dari guru saat masuk kelas. Guru menyebut satu-persatu nama absensi peserta didik kelas XII IPS 1, peserta didik yang disebut namanya dengan.

Menarik perhatian peserta didik, secara lisan guru mengucapkan salam pada saat masuk ke kelas, peserta didik dengan serempak menjawa salam dari guru saat masuk kelas. Guru menyebut satu-persatu nama absensi peserta didik kelas XII IPS 1, peserta didik yang disebut namanya dengan.

Memotivasi peserta didik, pada proses ini guru menanyakan apa yang mereka pikirkan mengenai materi yang akan mereka pelajari peserta didik terlihat diam dan hanya memperhatikan kedepan, kemudian guru meminta peserta didik mencari pengertian lain dari materi yang akan diajarkan sesuai dengan pemikiran peserta didik masing-masing, beberapa peserta didik terlihat mengangkat tangan dan memberikan pernyataan.

Struktur pelajaran, setelah guru merasa cukup dengan apa yang dipikirkan dan disampaikan peserta didik mengenai materi yang akan dipelajari, guru lalu menyampaikan cakupan materi dan penjelasan uraian kegiatan sesuai RPP, siswa pun memperhatikan struktur pelajaran disampaikan guru.

Mengingatkan antara materi yang sudah dikuasai dengan materi baru,pada proses ini 
guru menanyakan kepada peserta didik materi yang sudah diajarkan minggu lalu sebelum memberikan materi baru, peserta didik secara lisan mulai mengaitkan materi sebelumnya dengan materi yang akan mereka terima. Siswa diberi kesempatan untuk memerikan kesimpulan yang mereka tangkap sesuai dengan materi yang akan diajarkan.

Menanggapi situasi, pada proses ini interkasi edukaif guru dan peserta didik dikelas XII IPS 1 sudah berjalan dengan lancer, peserta didik terliha antusias mengikuti proses pembelajaran. Walaupun ada beberapa peserta didik yang pada saat guru menjelaskan masih sibuk mencatat, mengobrol dengan teman sebangkunya. Lalu guru mendekati peserta didik satu persatu dan meminta peserta didik untuk mengajukan pertanyaan, agar suasana belajar tidak bosan, beberapa peserta didik mengajukan pertanyaan kepada guru didepan kelas, peserta didik pun terlihat senang dan tidak terbebani dengan cara mengajar dan proses belajar dikelas.

Interaksi edukatif antara guru dan pesera didik pada saat inti pembelajaran ekonomi ang berlangsung dikelas XII IPS 1 SMAN 1 Jawai berjalan dengan baik, adapun kegiatan ang dilakukan dalam proses pembelajaran :

Menyampaikan informasi, secara lisan guru membarikan contoh-contoh lain yang baru yang berkaian dengan materi, pesera didik bias memahami semua penjelasan yang disampaikan guru didepan kelas. Guru meminta pesera didik untuk memberika opini masing-masing atau menambah informasi yang berkenaan dengan materi yang dipelajari, siswa terliha semangat mempersiapkan kalimat dan menyampaikan apa yang mereka pikirkan mengenai materi pelajaran hari ini.

Menerangkan, pada proses ini menerangkan secara lisan dan tulisan guru terliha berusaha memberikan pengertian mengenai materi yang akan dipelajari, peserta didik terlihat tenang pada saat mendengarkan penjelasan dari guru. Guru mencoba meluaskan pemikiran peserta didik dengan memberikan contoh-contoh pada kehidupan sehari-sehari mengenai maeri yang dipelajari, pesera didik diperbolehkan mencari informasi baru melalui internet atau membuka catatan dan buku masing- masing, beberapa dari peserta didik menanyakan hal belum mereka pahami, secara lisan guru langsung menanggapi dengan menjawab peranyaan dengan kaimat sederhana sehingga mudah dipahami oleh peserta didik, sesekali guru mendekai peserta didik untuk mengulang kembali penjelasan yang sudah disampaikannya.

Memberi motivasi, guru secara lisan meminta peserta didik untuk menanggapi apa yang telah disampaikan oleh guru maupun temannya, peserta didik terliha termotivasi dengan semua penjelasan yang disampaikan oleh guru.

Mengajukan pendapat pribadi, guru bertanya apakah peserta didik pernah melihat atau berada didalamnya seperti pada materi (contohnya pasar) peserta didik dengan semangat dan serempak menjawab pernah da nada beberapa yang menjawab sering ke pasar, guru secara lisan bertanya kepada peserta didik apakah peserta didik sudah memahami materi pembelajaran dan guru memberikan kesempatan kepada siswa untuk bertanya, siswa terlihat sangat anusias ketika diberikan kesempatan untuk bertanya.

Penjelasan maslah, pada proses ini guru dan peserta didik bersama memperjelas masalah atau materi kelompok, guru memberikan tanggapan mengenai pendapa peserta didik tentang materi yang telah dipelajari. Setelah semua kelompok menyelesaikan tugasnya guru meminta kelompok secera bergantian untuk dijelaskan hasil diskusi kelompok mereka didepan kelas, beberapa peserta didik memerikan tambahan pendapa kepada kelompok lain meskipun harus dengan bantuan guru didepan agar bias teratur, lalu guru mrnjelaskan kembali materi dan jawaban setiap kelompo peserta didik. Secara lisan guru bertanya kepada semue kelompok peserta didik apakah memahami materi yang disampaikan baik itu dari kelompok itu sendiri maupun kelompok lain, peserta didik terlihat memahami apa yang dipelajari melalui tugas kelompok ini, semua kelompok terliha saling menghargai pendapat satu sama lain.

Menutup diskusi, setelah semua anggota kelompok satu-persatu majukedepan kelas untuk mempresentasikan hasil diskusi mereka, guru memberikan konfirmasi kepada meraka terhadap hasil ekplorasi dan elaborasi peserta didik terhadap erbagai sumber, peserta didik terliha sudah memahami semua materi yang disampaikan baik dari guru maupun dari temantemanya guru meminta peserta didik untuk 
bersama-sama merangkum pokok-pokok pemikiran dan hasil dari diskusi kelompok yang sudah dilakukan oleh peserta didik, setelah itu guru memberikan motivasi-motivasi dan mendekati siswa yang belum akti untuk bertanya kepada peserta didik yang sudah mengerti.

Bentuk interaksi edukatif antara guru dan peserta didik pada saat menutup pembelajaran ekonomi yang berlangsung dikelas XII IPS 1 SMAN 1 Jawai, adapun kegiatan yang dilakukan guru dan peserta didik :

Merangkum inti pokok pembelajaran, pada proses ini, guru dan peserta didik secara bersama-sama membuat kesimpulan tentang apa yang sudah mereka diskusikan, peserta didik terlihat merangkum untuk semua materi yang telah diajarkan hari ini.

Memberikan dorongan psikologi kepada siswa, guru melakukan penilaian dan memberikan perhargaan bagi peserta didik yang sudah mengerjakan tugas dengan baik, pesera didik masih terlihat saling bekerjasama saling membantu teman-temanya yang belum paham, meskipun dari kelompok lain. Guru membuat peserta didik merasa proses pembelajaran menjadi menyenangkan dan bermanfaat.

Memberi petunjuk untuk pelajaran selanjutnya, guru meminta peserta didik untuk melakukan pengecekan ulang terhadap tugastugasnya yang belum tepat, setelah dianggap memahami materi yang telah disampaikan dan didiskusikan, guru memberikan tema materi yang akan dipelajari padapertemuan selanjunya, peserta didik terliha mencatat judul materi baru dibuku mereka masing-masing.

Mengadakan evaluasi, guru memberikan tugas individu kepada siswa, siswa terliha mengerjakan tugas sesuai dengan materi yang disampaikan guru, peserta didik juga terlihat mengerjakan tugas dengan baik dan tidak menyontek. Selanjutnya guru memberikan tugas rumah untuk peserta didik, agar peserta didik semakin memahami apa yang sudah. mereka pelajari hari ini. Peserta didik mencatat semua soal-soal untuk pekerjaan rumah. Setelah semua selesai, peserta didik diminta untuk menutup buku

Pelajaran ekonomi mereka, peserta didikmulai berdoa dengan dipimpin salah satu peserta didik, lalu peserta didik berdiri dan mengucap salam kepada guru, menandakan bahwa proses pembelajaran ekonomi dikelas XII I PS 1 sudah selesai.

Berdasarkkan hasil pengamatan peneliti, interaksi edukatif antara guru dan peserta didik dalam proses pembelajaran dikelas XII IPS 1 SMAN 1 Jawai diketahui sudah sudah berjalan dengan baik, meskipun masih ada beberapa peserta didik yang belum mampu melakukan interaksi dengan baik, baik kepada guru ataupun sesama temannya. Arah interaksi antara guru dan peserta didik dalam proses pembelajaran ekonomi dikelasa XII IPS 1, memiliki berbagai pola komunikasi, seperti pada saat membuka proses pembelajaran terjadi pola komunikasi antara guru dan peserta didik. Pada saat guru menjelaskan materi peserta didik mendengarkan dan bertanya sehingga terjadi komunikasi dua arah dan pada saat menutup pembelajaran ekonomi juga terdapat pola komunikasi yang melingkar, pada saat guru memberikan kesimpulan di akhir pembelajaran tterjadi komunikasi yang optimal antara guru dan peserta didik.

\section{Pembahasan}

Sekolah merupakan lembaga pendidikan yang memiliki peranan penting dan merupakan sesuatu kebutuhan setiap orang. Seorang anak akan mengalami perubahan dalam perilaku setelah memasuki sekolah. Hal ersebut menuntu sekolah terutam guru-guru agar mendidik peserta didik untuk berprilaku baik dan mampu menyesuaikan diri dengan semua proses dalam pembelajaran yaitu dalam melakukan interaksi edukatif hal ini senada dengan Narwoko dan Suryanto (2004 16) berpendapat bahwa interaksi edukatif adalah "terjadinya kontak social dan komunikasi"

Membuka proses pembelajaran dilakukan agar interaksi dalam pembelajaran harus terjadi kontak dan komunikasi antara guru dan peserta didik maupun peserta didik dengan sesame peserta didik. Interaksi edukatif pada saa membuka pembelajaran dilakukan dengan baik maka akan membuat peserta didik lebih nyaman dan lebih mudah melakukan kegiatan-kegiatan pada setiap proses pembelajaran, seperti yang dikemukan oleh ahli Mutchid ia berpendapat bahwa "kegiatan membuka pembelajaran adalah kegiatan dasar yang dilakukan oleh guru dan 
diterima oleh peserta didik. Interaksi dalam kegiatan membuka pembelajaran sangat diperlukan, agar dapat mencapai tujuan pembelajaran secara efektif, efisien, dan menarik.

Berdasarkan hasil observasi dan wawancara yang dilakukan peneliti di SMAN 1 Jawai proses membuka pembelajaran adalah yang mana guru sebagai komunikator yang merupakan awal dari kegiatan yagn dilakukan guru kepada peserta didik untuk memulai pembelajaran. Kegiatan ini memerlukan inerkasi yang baik karena pada proses ini adalah awal untuk peserta didik terarik.

Guru merupakan faktor penentu yang sangat dominan dalam pendidikan pada umumnya,. Sebagai pendidik guru harus memperhatikan aspek kepribadian peserta didik terutam dalam berinteraksi kepada guru maupun kepada peserta didik lainnya. Interaksi yang dilakukan guru dalam kelas pada saat proses pembelajaran menjadi penentu berhasil atau tidaknya pembelajaran yang dilakukan. Senada dengan diungkapkan oleh Muchith (2007:123124) "interaksi antara guru dan peserta didik terjadi karena jalinan dan hubungan sinergis antara komponen satu dengan komponen lainnya pembelajaran guru sentry dan peserta didik sentry tidak bias dikategorikan sebagai realitas pembelajaran sistemaik karena pola guru sentris akan menciptakan siswa pasif yang berakibat pada apatisme dalam diri peserta didik. Sedangkan peserta didik sentris akan melahirkan hasil yang tidak optimal" hal tersebu menuntut guru dan peserta didik harus melakukan interaksi yang baik dalam kegiatan pembelajaran terutama pada saat memberikan dan menerima materi pembelajaran.

Berdasarkan hasil observasi dan wawancara di SMAN 1 Jawai, bahwa dalam penyampaian materi pembelajaran guru dan peserta didik sudah melakukan interaksi yang baik, peserta didik sudah aktif dalam menerima, menanggapi dan berekplorasi dalam kegiatan pembelajaran. Interaksi yang dilakukan oleh adalah pola komunikasi kesegala arah.

Setiap sekolah dan setiap guru memiliki cara pembelajaran dan pengajaran didalam kelas yang berbeda sesuai RPP dan meode yang akan digunakan. Proses pembelajaran didalam kelas memerlukan banyak interaksi dan interaksi yang baik menentukan kebrehasilan peserta didik dalam memahami materi yang disampaikan oleh guru.

Berdasarkan hasil observasi dan wawancara yang dilakukan peneliti dikelas XII IPS 1 SMAN 1 Jawai, pada kegiatan penutupan pembelajaran ini, interaksi yang dilakukan guru dan peserta didik ini sudah cukup baik. Seperti yang dikatakan oleh siswa pada saat ditanya apakah siswa aktif dalam setiap proses pembelajaran, ia mengatakan bahwa "secara keseluruhan sih udah aktif bang, tapi tidak semua" (Fajar Baharudin, wawancara 17 oktober 2020). Dalam kegiatan penutup guru harus dapat memastikan bahwa peserta didik sudah memahami materi yang disampaikan, sehingga peserta didik sudah dapat membuat ringkasan maeri sebagai catatan seperi yang peneliti amati ketika melakukan observasi, terdapat beberapa hal yang dilakukan oleh guru untuk membuat kesimpulan secara bersama, siswa pun terlihat melakukan apayang diminta oleh guru hal ini dibenarkan oleh seorang siswa bernama Jaka Saputra, mengatakan "iya bang, setiap akhir pembelajaran ataupun akhir diskusi selalu membuat kesimpulan" (wawancara 17 oktober 2020).

Interaksi pada kegiatan penutup yang dilakukan oleh guru kepada peserta didik, serta dapat pula kepada peserta didik lainnya. Seperti yang peneliti amati ketika melakukan observasi, peneliti menemukan beberapa hal yang dilakukan oleh guru pada proses ini, guru terliha melakukan penilaian dan memberikan penghargaan kepada peserta didik yang sudah mengerjakan tugas dengan baik guru membuat materi yang diajarkan menyenangkan dan mudah dipahami, peserta didik terliha saling membantu teman yang kurang memahami materi pembelajaran, peserta didik meminta teman-temanya yang idak aktif turut aktif dalam mengikuti dan menjawab setiap pertanyaan.

Seperi yang peneliti temukan ketika melakukan observasi, peneliti melihat guru memberikan kesempatan kepada peserta didik untuk bertanya mengenai materi yang kurang jelas terlebih dahulu, guru memberikan ugas kepada peserta didik baik tugas individual maupun tugas kelompok sesuai dengan hasil belajar. Siswa terliha mengerjakan tugas yang diberikan dengan baik, akhir dari interaksi pada proses pembelajaran ini guru memberikan tugas rumah sesuai dengan materi yang diberikan. 


\section{SIMPULAN DAN SARAN \\ Simpulan}

Berdasarkan hasil pengamatan dalam penelitian dan pembahasan atas data mengenai analisis interaksi edukatif antara guru dan peserta didik dalam pembelajaran ekonomi kelas XII IPS 1 SMAN 1 Jawai, maka dapat ditarik kesimpulan secara yaitu kegiatan interaksi edukatif antara guru dan peserta didik dalam proses pembelajaran ekonomi yang diterapkan oleh guru mata pelajaran ekonomi kelas XII IPS 1sudah cukup baik disetiap pertemuan proses pembelajaran namun dalam metode pembelajaran yang kurang menarik untuk peserta didik sehingga membuat peserta didik kurang opimal dalam menyimak pembelajaran.

Adapun tahapan kegiatan pembelajaran dikelas yaitu membuka proses pembelajaran, kegiatan inti, dan terakhir menutup proses pembelajaran. Hal tersebut dapat dilihat dari hasil observasi dan wawancara yang dilakukan oleh peneliti, lebih khusus lag dapat disimpulkan sebagai beriku :

Pada tahap membuka proses pembelajaran oleh guru yang mencakup beberapa aspek yakni, menarik perhatian siswa, memotivasi siswa, struktur pelajaran, mengingatkan antara materi yang sudah dikuasi dengan materi Pada tahap membuka proses pembelajaran oleh guru yang mencakup beberapa aspek yakni, menarik perhatian siswa, memotivasi siswa, struktur pelajaran, mengingatkan antara materi yang sudah dikuasi dengan materi yang baru dan menanggapi situasi peserta didik. Dari indikator tersebut peneliti guru sudah melaksakan dengan baik diseiap pembukaan proses pebelajaran. Namun, ditahap mengingatkan antara materi yang akan dipelajari dan materi yang sudah dipelajari peserta didik masih kurang aktif karena memang ada yang belajar terlebih dahulu da nada juga yang tidak sama sekali.

Tahap menjelaskan materi/ kegiatan iinti pembelaaran disini guru sebagai pemberi dan penerima aksi yang mencakup beberapa aspek yang menunjang interaksi antara guru dan peserta didik yakni, menyampaikan informasi, memberi motivasi, serta mengajukan pendapat pribadi, semua hal peneliti perhaikan pada hasil observasi dan wawancara

Tahap menutup proses pembelajaran interaksi sebagai transaksi, yang mencakup beberapa hal yang dilakukan oleh guru dan peserta didik pada kegiatan terakhir ini ialah, merangkum pokok-pokok pelajaran, memberi petunjuk untuk pelajaran selanjutnya, dan mengadakan evaluasi.

\section{Saran}

Saran merupakan hal-hal yang disarankan oleh penulis berdasarkan hasil penelitian yang telah dilakukan. Melalui saran-saran yang diberikan, diharapkan hasil penelitian selanjutnya dapat lebih maksimal dan mendapatkan hasil sesuai dengan tujuan penelitian yang diharapkan.

Berdasarkan hasil dari penelitian yang diperolah oleh penelitti

serta pembahasan dari hasil tersebut, maka peneliti memberikan saran- saran sebagai berikut. semangat dalam belajar. Terlebih untuk semua guru mata pelajaran agar lebih memeperbaiki interaksi kepada peserta didik agar penyampaian materi dan tujuan dalam proses pembelajaran tercapai, dan lebih memberikan banyak ksempatan kepada peserta didik untuk berekplorasi dan bertanya

Kepada siswa kelas XII IPS 1, peneliti menyarankan agar lebih aktif pada setiap kesempatan yang diberikan oleh guru, berikan pendapa ketika melakukan diskusi kelompok, maupun ekplorasi danberkreatif dengan pemikiran-pemikiran yang sesuai dengan materi. Dengarkan penjelasan guru dengan baik dan mampu mengerjakan tugas-tugas dari guru dengan mandiri maupun kelompok dengan peserta didik lain, agar interaksi dalam proses pembelajaran tercapai dengan baik.

Kepada peneliti selanjutnya,peneliti menyarankan untuk meneliti dengan aspek yang berbeda. Aspek lain misalnya subjek yagn berbeda seperti penerapan interaksi edukatif dalam proses pembelajaran, dan sebagainya.

Dari hasil penelitian observasi, hasil wawancaara yang dilakukan untuk memperkuat hasil dari penelitian mengenai interaksi edukatif antara guru dan peserta didik dalam pembelajaran ekonomi dikelas 
XII IPS 1 SMAN 1Jawai ini sangat mempengaruhi prestasi belaar siswa. Dilihat dari proses pembelajaran yang dilakukan oleh guru dan peserta didik kelas XII IPS 1, prestasi yagn didapat siswa cukup memuaskan, khusunya untuk mata pelajaran ekonomi peneliti hanya menyarankan kepada siswa kela XII IPS 1 agar meningkatkan lagi prestasi belaarnya, lebih aktif dan membangun interaksi lebih baik lagi kepada sesame peserta didik lainnya.

\section{DAFTAR RUJUKAN}

Djamarah, S.B. (2010). GuruDan Anak Didik Dalam InteraksiEdukatif. Jakarta: Rineka Cipta.Internet

Emzir. (2014).Metodologi Penelitian Kualitatif Analisis Data. Jakarta: PT Raja Grafindo Persada

Sadirman.A.M. (2014). Interaksi Dan Motivasi Belajar Mengajar. Jakarta: Raja Gravindo Persada

Sugiyono. (2019). Metode Penelitian Kuantitatif Kualitatif Dan $R \& D$. Bandung: Alfabeta

Naim, N. (2016). Dasar-dasar Komunikasi Pendidikan. Jogjakarta: Ar- ruzz Media

Nawawi, H. (2015). Metode Penelitian Bidang Sosial. Yogyakarta: Gajah Mada University Press
Sudjana, N. (2014). Dasar-dasar Proses Belajar Mengajar. Bandung: SinarBaru Algensindo

Sujarweni, V.W. (2014). Metodologi Penelitian. Yogyakarta: Pustaka Baru Pres

Trianto. (2010). Pengantar Penelitian Pendidikan Bagi Pengembangan Profesi Pendidikan Dan Tenaga Kependidikan. Jakarta: Kencana Prenada Media Group

Slameto. (2010). Belajar dan Faktor-Faktor yang Mempengaruhi. Jakarta: Pustaka Indonesia

Yunsirno. (2012). Keajaiban Belajar. Pontianak: Pustaka Jenius Publishing

Sudjana, N. (2014). Dasar-Dasar Proses Belajar Mengajar. Bandung: Sinar Baru Algensindo

Galkiene, A. (2017). Educational Interaction of the Student With Behavioral Disorder in the Context of Tranformation of Educational Paradigms: The Case of an Educatinal Centre, 2(3), 40-50. Retrieved from https://dx.doi.org

Uzer,U.M(2013). Menjadi Guru Pofesional, Bandung: Remaja Rosdakarya 